\title{
Teaching French language through films: The cultural contents in French and Francophone films
}

\author{
Joesana Tjahjani* and Damar Jinanto \\ French Department, Faculty of Humanities, Universitas Indonesia, \\ Kampus Fakultas Ilmu Pengetahuan Budaya UI, Depok 16424, Indonesia
}

\begin{abstract}
Foreign language teaching in the current globalization era needs to compete with technological development. This competition is related to the discovery of digital technology-based methods to motivate learners to provide more interesting cultural content in language classes. For teachers from a different cultural background, authentic documents such as films are considered very effective in delivering cultural content. This research takes a French film, Intouchables, and a Canadian francophone film, Monsieur Lazhar, as a research corpus for their cultural content to be analyzed. The proper understanding of the two films' cultural content can inform a digital technology-based French-language teaching medium. To discover what strategies or formulas are used in teaching French with cultural-laden films as teaching media, requires studying the films by dissecting the structure of the text. Examination of the structure of the films was based on the theory of Boggs and Petrie (2008), equipped with in-depth reading to find signs in the text by referring to Buckland (2004); and also the identification of cultural content using the cultural approach by Stern (1992). The construction of a teaching plan with a language teaching approach by Damen (1987) and Byram (1997) will be the last step. This research provides an academic outcome that is a film structural analysis to identify cultural content in the two films. The second outcome is a practical categorization of cultural content utilized as a language teaching material.
\end{abstract}

Keywords: Cultural content; film; French language teaching; language in education

\begin{tabular}{|c|c|c|}
\hline $\begin{array}{c}\text { First Received: } \\
15 \text { November } 2020 \\
\text { Final Proof Received: } \\
27 \text { September } 2021\end{array}$ & $\begin{array}{c}\text { Revised: } \\
16 \text { April } 2021\end{array}$ & $\begin{array}{c}\text { Accepted: } \\
\text { 22 July 2021 } \\
\text { Published: } \\
\text { 30 September 2021 }\end{array}$ \\
\hline \multicolumn{3}{|c|}{$\begin{array}{l}\text { How to cite (in APA style): } \\
\text { Tjahjani, J. \& Jinanto, D. (2021). Teaching French language through films: The cultural } \\
\text { contents in French and Francophone films. Indonesian Journal of Applied Linguistics, } \\
\text { 11(2), 382-391. https://doi.org/10.17509/ijal.v11i2.29450 }\end{array}$} \\
\hline
\end{tabular}

\section{INTRODUCTION}

Language and culture are two inseparable things because language is one of the products of culture. With that said, language teaching is also inseparable from culture teaching. Salim (2017), stated that language and culture are two related aspects that are inseparable because language is culture. Teaching language is automatically teaching culture. Salim (2017) added that students could improve knowledge about lifestyles, behaviors, beliefs, and values by learning the language speakers' culture.

In line with Salim (2017), in terms of French language teaching, CECRL (Cadre Européen
Commun de Référence pour Les Langues, Common European Framework of Reference for Languages) has updated the teaching technique of European languages as a foreign language from conventional to an integrated method. The teaching focuses not only on linguistic aspects, such as phonetics, semantics, grammar, and vocabulary, but also on cultural aspects such as mindset, lifestyle, and beliefs. This approach is no longer only communicative but is also actionable (actionnelle). The format of the textbook has also been renewed and adapted to this method and approach. It is not

\footnotetext{
*Corresponding Author

Email: joesana.tjahjani@ui.ac.id
} 
uncommon to find materials discussing films in today's French-language textbooks.

Even though the textbook format has been adapted, it has not considered the massiveness of application-based digital teaching that is a new form of language learning of the era. In the 4.0 industrial revolution where digital technology is widespread, foreign language teaching must also compete with technological advancement. This competition is related to discovering digital technology-based methods to motivate learners in language classes; therefore, foreign language teaching in this era does not only rely on language textbooks. Therefore, films are expected to be a supporting media for teaching material that shows the activities of native speakers situated in a social context.

Other media textbooks for teaching are developed by foreign language teachers to create an enjoyable atmosphere when teaching in class. Teaching methods, such as playing games and quizzes, can help draw learners' attention to the material provided. Another method is watching films that can make the classroom atmosphere more lively. Learners' love for foreign language classes is expected to increase when friendly methods for learners of the current generation are used. The use of entertainment-related media, such as films, can encourage exploration of foreign language learners' receptions and develop their language competence. Albiladi et al. (2018) research showed that films as an authentic language learning source could effectively improve language skills, especially for speaking, listening, reading, vocabulary, and writing skills. Besides, film as a teaching medium can increase the cultural awareness of learners. What is needed to increase cultural awareness, especially foreign culture, is a study that can unpack the cultural content in authentic documents used so that student reception is more focused. Fauziyah and Tjahjani (2018) affirmed that films need to be studied to investigate the visual narratives' ideology. They said that the analysis of the text structure and narrative strategy of films could reveal the underlying theme upon which the narrative logic is built. With the comparison of the two films, the cultural content we learn from the films can be seen from the characters and various settings representing the social issues.

By using film as a teaching medium, learners can practice listening skills from native speakers. On the one hand, film teaching media can be a variation of foreign language teaching methods connected to the material from the textbook used. On the other hand, films provide additional knowledge to learners because there is cultural content that they see or hear. Habiňáková (2016) reminds us that cultural understanding cannot be separated from foreign language learning in a dynamic era. Knowledge of foreign cultures indirectly shows the interaction between cultures.
Young learners concurrently study habits, mindsets, and even the ideology of cultural identities different from them.

In teaching French through films, the content of French and francophone culture contained therein receives special attention. The cultural content can be used by teachers to prepare learners to accept cultural differences as an intercultural interaction when learning French. This additional knowledge can trigger a more comprehensive discussion about France's diverse cultural identities or francophone countries. Nurseto (2011) argues that creative teaching media can optimize learning outcomes due to a more pleasant learning atmosphere. However, Nurseto (2011) added that the development of teaching media should fulfill the VISUALS principle (Visible, Interesting, Simple, Useful, Accurate, Legitimate, and Structured) and systematic planning of each type of medium is needed to reach learning objectives because every medium has their characteristics, advantages, and disadvantages. From this explanation, it can be inferred that the preparation of teaching with film is a challenge in itself for French-language teachers. Teachers are required to make specific, planned, and systematic teaching preparations so that learning objectives are achieved.

Hammer and Swaffar's research (2012), which focuses on assessing the cultural content absorbed by learners in the classroom, put forward quantitative aspects to show student acceptance. The data obtained show that learners can see explicit cultural content in media like films, but they still need guidance to interpret every scene with cultural content. Learners' awareness needs to be increased to articulate the various cultural similarities and differences they see to be appropriately identified. For this reason, this study provides information regarding the appropriate strategy needed to describe cultural content in media such as films. This study proposes that dissecting film's structure can make it easier for learners to identify cultural content. Chun et al. (2016) also discussed the problem of perceiving cultural content, who want to help learners in technology-based language teaching through critical attention to cultural codes that exist in the text structure, context, meaning, and ideology that they encounter in various media. The researchers believe that language teaching to represent, express, and understand foreign cultures cannot be found automatically. The teacher's experience in understanding the text, technology, and teaching strategies is essential for language use at several levels of language proficiency.

Based on the presented background, two French-language films, Intouchables and Monsieur Lazhar, can be the proper teaching material to increase learners' understanding when facing intercultural interactions as they are learning French. Both films have many achievements, including 
being featured at international film festivals. The films show interracial interactions set in similar contexts in France and Canada. We use these two films to show that black and Arab can be seen as powerful races in France and Canada as represented by the main characters in the films. Multicultural discourse with two different types of relationships presents issues such as discrimination, cultural identity, and power relations which can be studied when paying attention to the French language used. These two research corpuses are relevant for those who study French and Francophone culture and French language learners who want to study the culture at the same time.

The cultural understanding is related to the social issues seen in both films concerning the theme of French and Canadian immigrants. The film Intouchables by Olivier Naakache and Éric Toledano, released in 2011, tells the friendship story of a Parisian millionaire and his Senegal-descent caretaker who lives in Paris banlieue (suburbs). Philippe, who has an abundance of wealth, but must live with his physical disability, forces him to have a caretaker, Driss. Driss and Philippe's togetherness becomes interesting as we see two people with different cultural identities can interact well. The same goes for the film Monsieur Lazhar by Philippe Falardeau, which was released in 2011, which also tells the story of an immigrant who applied to be an elementary school teacher in Canada. Bachir Lazhar saw this job opportunity after an incident with one of the school's teachers who committed suicide. Bachir Lazhar, a refugee from Algeria in Canada and has no teaching experience, finds it challenging to get a job. In this school, there is a cultural clash between Bachir Lazhar and the Canadian education system that is different from his experience in Algeria, which is an interesting topic to learn in the classroom while learning French.

The interaction between different identities becomes an indispensable topic of cultural study to open students' eyes to the diversity of cultures in the world. Film is the most comprehensive medium and the most representative portrait of culture with authentic interactions from everyday language spoken by native speakers. There are several previous studies with different topics and approaches to Intouchables such as constructing a negative portrait of womanhood (Schrambach, 2013), competing transnationalisms in contemporary French cinema (Michael, 2014), and the legacy of French colonialism plays in aesthetic representations of race and gender in contemporary France (Fişek, 2018). Meanwhile, several studies about Monsieur Lazhar that can be mentioned include an aspect of forms of address and cultural understanding (Tarte, 2014), a picture of an ideal immigrant in the neoliberal Québécois imagination (Labidi, 2015), and an exploration of politics, pain, and power in Monsieur Lazhar (Gürses, 2020).
Research on cultural content in teaching foreign languages is an exciting topic in applied linguistics studies in language teaching. Some researchers, such as Habiňáková and Nguyen, see how important a cultural approach is in language teaching. Habiňáková (2016) discusses the teaching of foreign languages with integrated cultural content. Habiňáková (2016) shows a model of intercultural communicative competence. This competency is considered very useful for teaching foreign languages by balancing language skills with communicative competencies from different cultures. Thus, the cultural content integrated into language teaching has a good influence on learners. This argument corresponds to that of Darmawangsa et al. (2020) who examined at communication apprehension in foreign language learners. They said that it is essential to provide positive support to students by learning how to construct an environment where learners also engage in positive behaviors. Therefore, we can consider that films as teaching material can be strategies toward language anxiety, particularly learners' communication apprehension.

Nguyen (2017) also sees the positive influence of cultural content in language teaching, contending that cultural content presentation has a unique role in language teaching and learning. Nguyen's focus is to divide the learning outcomes of the cultural content into three levels: cultural knowledge as the initial level, cultural awareness at a deeper level, and cultural competence as the most profound level, including cultural knowledge and awareness in it. The output that shows the learner's reception of cultural content can be evaluated towards the end of each session's discussion. This idea is related to the studies of Rajprasit (2020) that concern critical intercultural awareness. To help the learners understand themselves better, they should understand their own cultural perspectives and be able to make general comparisons between their own culture and other cultures. Rajprasit said that this understanding of intercultural awareness could avoid cultural stereotypes. Therefore, learners can mediate and negotiate in communicative situations in terms of practices in intercultural communication. This output can be seen in the teaching materials for teaching French through a film by Anne-Christine Rice (2013) by dividing it into three with the names "première approche", "approfondissement", and "pour aller plus loin". Thus, to prepare language teaching materials through cultural products, such as films, it is necessary to consider the learners' outcomes.

Cultural products are prepared as language teaching materials to analyze cultural content in language teaching through films. Researchers like Yalçın focus on film, which is considered useful for learning the language and its cultural aspects directly. Yalçın (2013) has a similar view regarding 
cultural content and language teaching, which are inseparable because learners indirectly need to understand the associated culture when learning a language. The interrelation between language and its cultural content can be used to foster intercultural understanding and understand universal values so that tolerance for different cultures will be more substantial. Yalçın considers film as the appropriate medium to develop an understanding of cultural diversity.

Tognozzi (2010) and Pfaff's (2014) analysis also supports film as an appropriate medium as a means of intercultural communication in language teaching. Tognozzi's research (2010) evaluated the learning outcomes in university classrooms, showing that film can improve students' language fluency. Tognozzi's focus is on pronunciation, intonation, and paralinguistic elements that can motivate learners to see specific aspects of the culture that learners are learning about. Pfaff (2014) also examined the use films at the university level produced by French-language directors, such as François Truffaut, Jean-Luc Godard, and Ousmane Sembène. His study found that films can be used as a similar material in a phonetic lab by taking footage clips for the learner to recite repeatedly. Pfaff (2014) also sees that learners can find cultural themes from the films, such as youth, family, education, religion, justice, work, and interracial interactions in France and West Africa. Thus, all researchers have strong reasons to believe that cultural products, such as films, show their success in finding cultural content integrated into language teaching to make learners close to the language being learned.

\section{METHOD}

This research uses French film Intouchables and Canadian francophone film Monsieur Lazhar as the research corpus. Both films show cross-cultural interactions between local residents and immigrants. The film structure study is useful for interpreting cultural content based on its narrative and cinematographic structures. After obtaining data regarding the cultural content by linking language and culture according to Damen (1987) and Byram (1997), this element was then identified as French learning teaching material based on the European Framework of Reference for Language Teaching (CECRL) levels A1-B2. The cultural content teaching strategy is divided into the categories of première approche, approfondissement, and pour aller plus loin adjusted to the level of language proficiency (Rice, 2013).

The initial stage of this research dissects the film's structure to allow for the identification of films based on the dramatic structure described by Boggs and Petrie (2008), which places the plot of the film into four parts: exposition, complication, climax, and denouement. Boggs and Petrie (2008) explain the four parts briefly as follows: (1) Exposition: this first part of the story introduces the characters, shows their interrelationships, and places them within a reasonable time and place. (2) Complication: a conflict begins and grows in clarity, intensity, and importance. This part is usually the most extended section. (3) Climax: the conflict at this part is resolved when the complication has reached its point of maximum tension. (4) Dénouement: this is the part in which a state of relative equilibrium returns.

The structure of this text is adapted from Buckland (2004) to find out how a text presents cultural content that appears based on reality. Buckland (2004) illustrates the meaning of the sign in text using the following chart:

\section{Figure 1 \\ Structure Chart of Text Concept as Social Representation

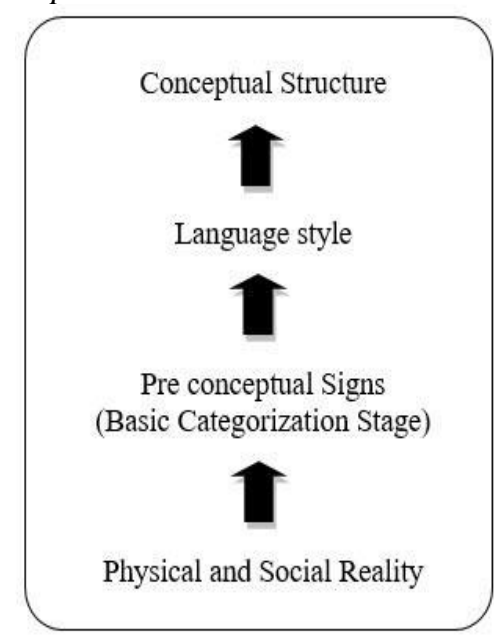

Based on Buckland's chart of sign formation, it can be understood that a text can be a sign that has a cultural concept of social reality through several stages. Initially, the reality in society is selected to be presented as a sign that can be generally identified as a theme in the text. This theme's choice is given a language style, such as metaphor and metonymy, to become a cultural product that, in turn, can be read by researchers as a complete sign with cultural content.

\section{FINDINGS AND DISCUSSION \\ Cultural content in reading film}

One of the benefits of teaching foreign languages using film as a teaching material, according to Yalçın (2013), is cultural promotion to create useful intercultural understanding. A film can be understood in detail when its structure is dissected. Learners can read the film's narrative material to ease understanding of the meaning of the signs given through the film's 'body language', namely images and sounds (Tognozzi, 2010). A film can be 
analyzed through its plot, characters, setting, and theme of the film with visual and aural aspects that support it. In the film's narrative structure, from exposition to the denouement, the characters' introduction is the most crucial part to be used as initial material for understanding the film. Learners can understand the logic of the film, thus helping learners retell the story's contents according to the understanding of the text. The relationship between characters becomes a material that can be explained in detail to stimulate learners to find the meaning of stories and characters.

The settings of place and time are also vital elements to describe and find patterns of character interactions with other characters or support miseen-scène elements, such as the costumes and props used. The film's narrative structure as a text as a teaching material can be arranged in a series of stories consisting of 4 plot stages: exposition, complication, climax, and denouement (Boggs \& Petrie, 2008). With the stages well-understood, learners can retell the film story's logic using their own words based on their understanding. It becomes a learning process that can be evaluated for the understanding of the received text. Based on the film Intouchables and Monsieur Lazhar, the division of these stages generally shows indicators that are depicted in Table 1.

Table 1

Plot Stages in Intouchables and Monsieur Lazhar

\begin{tabular}{|c|c|c|c|c|}
\hline \multirow{2}{*}{ Film } & \multicolumn{4}{|c|}{ Dramatic Structure } \\
\hline & Exposition & Complication & Climax & Dénouement \\
\hline Intouchables & $\begin{array}{l}\text { Race and cultural } \\
\text { identities } \\
\text { descriptions }\end{array}$ & $\begin{array}{l}\text { Ignorance of cultural } \\
\text { stereotypes }\end{array}$ & $\begin{array}{l}\text { Adaptation with different } \\
\text { cultures }\end{array}$ & Friendship \\
\hline Monsieur Lazhar & $\begin{array}{l}\text { Clash of identity and } \\
\text { culture }\end{array}$ & $\begin{array}{l}\text { Insinuation and warning } \\
\text { towards a different culture }\end{array}$ & $\begin{array}{l}\text { Rejection of different } \\
\text { cultures }\end{array}$ & Separation \\
\hline
\end{tabular}

Based on the table of plot stages that unravel the logic of the two films, the differences in the two films from the beginning to the end of the story can be seen. The film Intouchables shows the identity of the character at the beginning of the film descriptively. There is no significant conflict because the job interview process at the beginning of the film fits Driss's knowledge against Philippe, who equalizes their cultural backgrounds. Driss' cluelessness of Philippe's high-class culture was counteracted by Driss' limited knowledge curbed by a banlieue environment. The film Intouchables' initial scene describes the parallels between Driss and Philippe, not based on the conventional values practiced in society. The characters' alignment in this plot is a little different from Monsieur Lazhar's film, which clashes with Bachir Lazhar's cultural background with the cultural conventions of the Canadian school world. Monsieur Lazhar, as a foreigner, deeply feels that his habits are different from other teachers, as well as from his students, even though his students also have different cultural backgrounds. From the beginning of the film, it has been shown that the uniformity of individuals with different identities in Canada is stronger than in France, whose people tend to accept these differences as they are, without any strict uniformization system.

In the film Intouchables, the presence of the characters, Driss and Philippe, who look physically different, can be interpreted as the theme of differences in racial and cultural identities in this film. It is characterized by physical appearance, manner of dressing, and speaking style. However, the contrast shown is not accompanied by either party's domination, so that the more dominant character does not exist. Thus, Driss and Philippe's interaction is positioned on par with the equally polite language despite different accents. The film chooses to give both characters knowledge that shows the balance strengths of each character. Even in the development of the story, the balanced positions of Driss and Philippe are maintained. Therefore, each character is seen to help and need each other. A different interaction is shown in the police's presence, which shows the stereotypes that exist in France about immigrants. This distinction can be seen from the level of dialogue between Driss, Philippe, and the police regarding their speaking style.

The cultural content in the film's exposition of the introduction of the clash of identities between immigrants and several characters is seen in Monsieur Lazhar. In this film, Bachir Lazhar introduces himself initially, and his presence does not seem to get immediate acceptance. This is also supported by Bachir Lazhar's behavior, which shows his original identity as an immigrant in Canada by practicing several Algerian habits acquired by Bachir Lazhar. The rejection of Bachir Lazhar's cultural identity has been seen since the film's exposition and sparked small conflicts during Monsieur Lazhar's teaching at the school. Some negotiation can be seen with Monsieur Lazhar's acceptance as a teacher. Monsieur Lazhar's teaching materials, which are considered conventional, also do not experience significant contradictions throughout the story. The rejection occurred when it was known that Monsieur Lazhar had deceived the school residents with his false identity. The stern refusal at the end of the story implies Canada's duality, which is generally open to immigrants working in Canada but applies a closed system because they have to follow correct procedures. 
From the plot that allows students to understand the logic of the film's story, cultural content is also immediately visible by identifying the characters' identity which becomes an indicator of a culturally charged material when learning foreign languages. Identification of characters as intercultural communication that can be accrued when watching the film Intouchables and Monsieur Lazhar is shown in Table 2.

Table 2

Character Identification in Intouchables and Monsieur Lazhar

\begin{tabular}{|c|c|c|c|}
\hline \multirow{3}{*}{$\begin{array}{l}\text { Film } \\
\text { Intouchables }\end{array}$} & Character & Cultural Identity & Cultural Attribute Attached \\
\hline & Driss & $\begin{array}{l}\text { An African, black-skinned, living in the } \\
\text { banlieue, living more communally }\end{array}$ & Leather jacket, jeans, R\&B music \\
\hline & Philippe & $\begin{array}{l}\text { White-skinned, living in an upscale } \\
\text { Parisian house }\end{array}$ & $\begin{array}{l}\text { Wheelchair, luxury items, classical } \\
\text { music, high art }\end{array}$ \\
\hline Monsieur Lazhar & $\begin{array}{l}\text { Bachir Lazhar } \\
\text { Students }\end{array}$ & $\begin{array}{l}\text { Algerian, Arabic-descent } \\
\text { Multi-ethic, Canadians }\end{array}$ & $\begin{array}{l}\text { Food, music taste } \\
\text { Name, English proficiency }\end{array}$ \\
\hline
\end{tabular}

Based on Table 2, the differentiation of characters looks significant to show the problem of identity in the story. The issue of cultural identity is the main focus in both films. This is supported by several details attached to the characters to strengthen the issue of cultural identity differences. The differences shown directly, like in the film Intouchables, can provide clues to anyone watching, such as Berlioz's name that can provide two different references: (1) famous classical musicians for showing high-class tastes, and (2) common names used in France. From the different references to Berlioz's name, it can be explained that the name which is considered a big name for Philippe can have different meanings with Driss's knowledge that is limited to his environment in the banlieue.

Some of the cultural phenomena mentioned in each film can show the country's peculiarities, such as France, with its downtown and banlieue life, and Canada with immigrant acceptance. The two films can provide meanings to the cross-cultural interactions in France and Canada, which are different even though both countries speak French. This can be seen from the allusions made by other characters to immigrant figures who are present in the film. Attention to immigrant characters' reactions can be seen through the gestures and language used by other characters. This cultural content can complement the information in learning French through film media.

Apart from the plot and characters, the setting can indicate cultural language learning when looking at daily conversations because it relates to the characters' habits when they are in a specific setting, either in a particular place or in a specific season. This can be seen from how they dress, the conversation that is formed, to the stock character used. Proficiency in French can also be practiced by looking at the diction and expressions used by the characters. Several settings of places that can be indicators of cultural content in both films are shown in Table 3.

Table 3

Cultural Content Identification in Film Intouchables and Monsieur Lazhar

\begin{tabular}{|c|c|c|c|c|}
\hline Film & $\begin{array}{c}\text { Setting } \\
\text { Indicator }\end{array}$ & $\begin{array}{c}\text { Setting } \\
\text { Description }\end{array}$ & Setting's Signature & Meaning \\
\hline \multirow[t]{2}{*}{ Intouchables } & $\begin{array}{l}\text { Deux Magots } \\
\text { café }\end{array}$ & $\begin{array}{l}\text { Parisian coffee } \\
\text { shop }\end{array}$ & $\begin{array}{l}\text { A luxurious cafe that is } \\
\text { open until dawn }\end{array}$ & $\begin{array}{l}\text { Cafe displays the taste of rich } \\
\text { people in Paris. }\end{array}$ \\
\hline & Art gallery & $\begin{array}{l}\text { A place to buy } \\
\text { and sell } \\
\text { artworks }\end{array}$ & $\begin{array}{l}\text { Paintings are sold at high } \\
\text { prices }\end{array}$ & $\begin{array}{l}\text { One of the places that indicate } \\
\text { upper-class society }\end{array}$ \\
\hline \multirow[t]{2}{*}{ Monsieur Lazhar } & School & $\begin{array}{l}\text { A place where } \\
\text { students learn }\end{array}$ & $\begin{array}{l}\text { An education method that } \\
\text { more actively involves } \\
\text { students }\end{array}$ & $\begin{array}{l}\text { The latest class strategy that is } \\
\text { considered the best teaching } \\
\text { quality }\end{array}$ \\
\hline & Courtroom & $\begin{array}{l}\text { Courtroom to } \\
\text { settle legal } \\
\text { issues }\end{array}$ & $\begin{array}{l}\text { Tension in the courtroom } \\
\text { and the firmness of } \\
\text { decision-making }\end{array}$ & $\begin{array}{l}\text { Justice room to show the } \\
\text { country's stance on immigrants }\end{array}$ \\
\hline
\end{tabular}

The settings in the film Intouchables and Monsieur Lazhar show several significant places to represent the social practices that occur in them. Places such as cafes, art galleries, schools, and courtrooms can represent socio-cultural issues that can be interpreted when watching movies. The scene where Driss protests the food that is supposed to be cooked in a cafe shows a clash of cultures because there are different values. The same is true for Bachir Lazhar who changed the classroom arrangement according to his experience in Algeria. The method of teaching language, especially French, by Bachir Lazhar, which tends to be conventional, shows the problem of cultural differences in Canada even though in the end there is no conflict with the conventional teaching style. In this case, Canada seems to show a position that is concerned with education results in schools when students can receive it well, not a matter of uniformity of educational. 
Based on the dissection of the film structure that is carried out to strengthen the teaching of cultural content in French classrooms, finding the theme becomes the basis for students to understand the film's content. The two films' themes can be said to be similar because they relate to immigrants and social issues that can be found in France and Canada.

\section{The placement of cultural content in foreign language teaching}

Films with audio-visual material used as teaching materials for teaching foreign languages can be categorized as authentic oral teaching materials. The films for teaching materials can be selected according to the learners' language skills in the class. Films can be supporting material taught in class to see the pragmatic aspects of everyday language use. In this study, the film Intouchables provides an overview of the French language used in France as well as teaches the practice of the language in everyday life, especially in Paris. Likewise, with Monsieur Lazhar, this film shows the interactions between immigrant cultures and local residents in Canada, especially Montreal, who uses French in their daily lives.

There are three categories that can be learned from the French films in French as a foreign language class. A film can be used as a reference to see three categories which can be as follows: (1) les traits de l'oralité, which is related to its linguistic aspects (phonetics, syntax, and semantics), (2) le jeu social, which is related to the use of language socially and culturally, (3) le corps, which is related to the body language of the speaker and/or interlocutor. In this case, teachers need to identify differences in language symptoms, especially in categories 2 and 3 (le jeu social and le corps) because usually teachers only focus on linguistic aspects when teaching in class. This division can be seen further at the levels of learning with films in the following stages: (1) Language Development, to analyze aspects of language; (2) Authentique Learning, which looks at aspects of body language in practice in native speakers; (3) Selflearning/Autonomy, when learners try to imitate what is learned; and (4) Cultural Awareness, to increase understanding of cultural content in film scenes, that is explored more deeply (Albiladi et al., 2018).

In the films Intouchables and Monsieur Lazhar, there are similarities at the beginning of the film when introducing Driss (Intouchables) and Bachir Lazhar (Monsieur Lazhar), who enter someone's room for a work-related process. Their sudden presence did not prompt the people in the room to invite them to sit down. Rejection like this is seen in both films with the same pattern and process. Driss and Bachir Lazhar seemed to dominate the conversation, so it seemed convincing that they mastered the room's topic. The brief interviews that showed Driss and Bachir Lazhar's original identity as immigrants became an intercultural negotiation so that they can be seen as equal to other local residents. In introducing Driss and Bachir Lazhar at the beginning, teaching materials can be grouped and adjusted based on the learners' level of language skills.

Referring to the book Rice (2013), the distribution of teaching materials can be grouped into three parts, namely the première approche, approfondissement, and pour aller plus loin. The three sections can represent the level of proficiency in French based on Enseigner le FLE (français langue étrangère) Pratique de classe which lists two abilities in spoken language teaching, namely listening and speaking skills. Therefore, French teaching can be adjusted by grouping the level of proficiency as standardized by the CECRL through the division of three levels of proficiency into beginner level (A1 and A2); intermediate level (B1 and B2); and trained levels (C1 and C2). Films can be used as teaching materials that can improve listening and speaking skills because they can stimulate learners to listen more carefully while obtaining additional cultural content. This cultural content can be traced from language practices in certain places or certain cases so that learners can understand the communication when in that position. In other words, teachers need to unpack the contents of the film so that they can adapt the film as teaching material to the teaching materials prepared, especially for beginners and intermediate levels (A1 - B2) for the films Intouchables and Monsieur Lazhar.

Table 4 shows the teaching materials developed from the film Intouchables when used in French classrooms. Apart from paying attention to dialogues, which can be used as communication skills learning from authentic documents such as ordering food at a cafe or a job interview process, preparation for cultural content can also be done. The première approche stage is more to identify things that are clearly visible in the film. Learners can mention what appears in each scene or restate it if there is an explicit explanation. At a further stage, in the approfondissement stage, students are expected to be able to explain what appears in the film in more detail, for example, the luxury of Philippe's house by comparing it to Driss' house. The knowledge that the Paris banlieue citizens go to Paris by the RER leads learners to find information about the RER to connect the banlieue area with the city center. At the pour aller plus loin stage, learners are expected to seek intertextuality to strengthen arguments about social issues that appear in films, such as the issue of immigrant discrimination in France or the problem of banlieue and multiculturalism in France. 
Table 4

Teaching Material Indicator from Intouchables

\begin{tabular}{|c|c|c|c|c|}
\hline No. & $\begin{array}{l}\text { Teaching } \\
\text { material }\end{array}$ & $\begin{array}{l}\text { Première approche } \\
\text { (A1) }\end{array}$ & $\begin{array}{l}\text { Approfondissement } \\
\text { (A2-B1) }\end{array}$ & $\begin{array}{l}\text { Pour aller plus loin } \\
\text { (B2) }\end{array}$ \\
\hline 1 & $\begin{array}{l}\text { Character } \\
\text { identification }\end{array}$ & $\begin{array}{l}\text { Physical and personality } \\
\text { descriptions } \\
\text { - } \quad \text { Driss's introduction in the } \\
\text { interview } \\
\text { - } \quad \begin{array}{l}\text { Driss and Philippe's Clothing } \\
\text { style and taste }\end{array}\end{array}$ & $\begin{array}{l}\text { - The relation between Driss } \\
\text { and Philippe } \\
\text { Language style used } \\
\text { between Driss and Philippe } \\
\text { - Comparison of Driss and } \\
\text { Philippe's lives }\end{array}$ & $\begin{array}{l}\text { - Understanding of racial } \\
\text { and cultural stereotypes } \\
\text { Discourse domination } \\
\text { and discrimination } \\
\text { between characters }\end{array}$ \\
\hline 2 & $\begin{array}{l}\text { Setting } \\
\text { description }\end{array}$ & $\begin{array}{l}\text { Description of place by } \\
\text { observing items inside the } \\
\text { house, cafe, or art gallery } \\
\text { Description of the difference } \\
\text { between Driss and Philippe's } \\
\text { homes } \\
\text { Identification of seasons and } \\
\text { their relations with the daily } \\
\text { lives of the French (clothing, } \\
\text { behaviors) } \\
\text { Description of items that } \\
\text { indicate certain time setting }\end{array}$ & $\begin{array}{l}\text { Opinions about places that } \\
\text { emphasize Driss and } \\
\text { Philippe's identities } \\
\text { Explanation about family } \\
\text { lives based on the different } \\
\text { homes } \\
\text { Explanation about items or } \\
\text { habits that are old or new } \\
\text { traditions }\end{array}$ & $\begin{array}{l}\text { - Symbolic meanings of } \\
\text { items for Philippe and } \\
\text { Driss } \\
\text { - Segregation between } \\
\text { banlieue and city center }\end{array}$ \\
\hline
\end{tabular}

When looking at the teaching material from Monsieur Lazhar, the main theme found is similar to the film Intouchables, namely the problem of immigrant identity. The difference between Driss and Bachir Lazhar is the background to their entry into a particular country. Driss has entered France as a child and lives in France with his adoptive parents, while Bachir Lazhar is an asylum seeker from Algeria who lives in Canada. With different backgrounds, Bachir Lazhar's problems are more complicated regarding the acceptance of local residents. This basic understanding becomes an asset for French learners when watching this francophone film from Canada. Table 5 displays the findings for teaching material from the film Monsieur Lazhar which can be compared with the film Intouchables' previous material.

Table 5

Teaching Material Indicator from Monsieur Lazhar

\begin{tabular}{|c|c|c|c|c|}
\hline No. & $\begin{array}{l}\text { Teaching } \\
\text { material }\end{array}$ & $\begin{array}{c}\text { Première approche } \\
\text { (A1) }\end{array}$ & $\begin{array}{c}\text { Approfondissement } \\
\text { (A2 - B1) }\end{array}$ & $\begin{array}{c}\text { Pour aller plus loin } \\
\text { (B2) }\end{array}$ \\
\hline 1 & $\begin{array}{l}\text { Character } \\
\text { identification }\end{array}$ & $\begin{array}{l}\text { Physical and personality } \\
\text { descriptions } \\
\text { Bachir Lazhar's self- } \\
\text { introduction to apply as } \\
\text { a teacher } \\
\text { Description of student } \\
\text { and another teacher }\end{array}$ & $\begin{array}{l}\text { Opinion about the issue } \\
\text { experienced by Bachir Lazhar } \\
\text { The different teaching method } \\
\text { used by Bachir Lazhar and } \\
\text { other teachers } \\
\text { - } \quad \text { Difference language used } \\
\text { Background of Bachir } \\
\text { Lazhar's previous life }\end{array}$ & $\begin{array}{ll}- & \text { Refugee issues in } \\
\text { Canada } \\
\text { - } \quad \text { Intercultural tolerance in } \\
\text { Canada }\end{array}$ \\
\hline 2 & $\begin{array}{l}\text { Setting } \\
\text { description }\end{array}$ & $\begin{array}{l}\text { - Classroom description } \\
\text { - Daily activities at } \\
\text { school }\end{array}$ & $\begin{array}{l}\text { - The difference between Bachir } \\
\text { Lazhar and Canadian students' } \\
\text { education structure } \\
\text { Different values between } \\
\text { Bachir Lazhar and students or } \\
\text { other teachers }\end{array}$ & $\begin{array}{l}\text { - The unconventional } \\
\text { education system in } \\
\text { Canada } \\
\text { - Court system in Canada }\end{array}$ \\
\hline
\end{tabular}

In addition to the school background that can be studied a lot from the film Monsieur Lazhar, using language in Canada is an exciting topic to raise, especially to see francophone French speakers. Some of the language codes that distinguish French spoken in Canada can be learned from the expressions spoken in this film, in addition to accents that can be studied more deeply. Several expressions that can be found from the film, such as: (1) "berlingot" to say milk and picket codes to prepare packaged milk every morning in class; (2) "c'est pas ma fault" as self-defense when accused of guilt; (3) "bye" became the usual substitute for "au revoir". In other words, it is very common to insert English into French conversations in Canada.

The Language and Culture Teaching Design is made after identifying teaching materials so that teaching becomes systematic and directed according to learners' abilities in the classroom so that learning targets are achieved. The Language and Culture Teaching Design is based on Damen's (1987) and Byram's theory (1997). They argue that language and culture teaching is a learning process that lasts a lifetime. The objectives of the lifelong learning process, which include both cognitive and affective aspects, are: (1) to show cultural differences 
between the first and second languages; (2) foster a sense of tolerance and acceptance of the plurality of values, behavior, and beliefs in the culture of the target language; (3) understand the novelty and differences that exist in the target language; (4) able to accept similarities, differences, and cultural influences on life, to develop intercultural competence in communication and self-adaptation of learners. The two films can be used as references for teaching materials that show French use in everyday life. These two films present similar social issues about immigrants and can provide an overview of the tolerance that exists in France and Canada. Learning French by using Monsieur Lazhar helps learners to understand the complexities of culture through French expression in Canada. This cultural complexity is deep with the issue of Algerian immigrants which shows that French presence in Canada connects two different cultural identities, in this case, Canada and Algeria. Gürses (2020) states that Monsieur Lazhar presents the tension between stability and movement in visual, linguistic, and political contexts through the figure of the refugee. With the help of intertextuality, learners can understand the context of socio-cultural issues in France or Canada. For this point, this research becomes important. The teaching materials in the two films make it easier for students to understand the meaning behind the dialogues, scenes, and interactions between characters. Previous research conducted by Fişek (2018), Gürses (2020), Labidi (2015), Michael (2014), Schrambach (2013), and Tarte (2014) related to issues of race, class, gender, and discourse about the integration, assimilation, and diversity of Québec society, will further broaden students' insights in understanding the cultural content in the two films. This deeper understanding can strengthen the arguments when learners practice speaking skills for levels B1 or B2.

Byram (1997) added that developing intercultural communication in learners is crucial because it can shape a person's character to become a person who has free and critical thinking and a social spirit so that it helps them establish a relationship with the world. Intercultural communication development is based on four aspects, namely knowledge, competence, sensitivity, and personality. Knowledge relates to national and cultural identities, such as daily behavior, geographic and social space for movement, social interactions, arts, and cultural products. Competence is related to the ability to observe and identify values, patterns, and themes in both verbal and nonverbal cultural aspects to generate cultural hypotheses that ease learners' adaptation to different cultural environments. Meanwhile, the sensitivity and personality to culture are related to the similarities and differences in the culture of the first language and the target language to foster a sense of curiosity, tolerance, and acceptance of the similarities and differences in the culture.

Several previous studies which are designated for people who want to see cross-cultural interactions from the films Intouchables and Monsieur Lazhar have focused more on cultural content. There is also a study that only looks at the use of French in films that prioritize language learning. In this study, the elements of cultural content and language learning are inseparable. This study explains that when providing French language learning materials through French and francophone films, cultural content will always be one of the materials that need to be taught to learners to directly understand the cultural interactions of native speakers.

\section{CONCLUSION}

It is important for French learners to understand cultural content when watching and looking at the structure of the films Intouchables and Monsieur Lazhar. The interaction of characters with the settings that build the daily atmosphere in the films can be interpreted as a cultural practice considered normal in certain countries. Simple dialogues that are carried out to build the atmosphere can be studied as a form of cultural communication. In addition, communication problems, such as distraction when conveying messages or how to behave when there is a communication failure, such as wanting to protest at a restaurant depicted in the film Intouchables or how to visit a friend's house as in Monsieur Lazhar shows the latest French teaching principles with the actionable approach. With the actionable approach through examples of scenes in the film, learners will understand better when they experience similar situations, including what kind of language expressions are usually used by the French and Canadians.

When teachers use technology such as film as teaching materials, this text provides a means for language learners to realize, reflect on, and understand communicative practices in a particular culture. Strategies to discover how language is used and its social consequences are the key to developing communicative skills in learning foreign languages (Chun et al., 2016). Through teaching French like this, learners will feel better prepared for some of the situations depicted in the film, as simple as by seeing daily activities carried out in the morning, afternoon, evening, and night. The cultural content in the film Intouchables and Monsieur Lazhar that is analyzed can be informed to learners as a form of intercultural communication when learning French in the context of life in France and Canada. Teaching materials like this can prepare the learners mentally when they see the actions and reactions of native language speakers that look more real in the film. 


\section{ACKNOWLEDGEMENTS}

This research is funded by the Faculty of Humanities, Universitas Indonesia, through Hibah Riset Klaster (Interdisciplinary) 2020.

\section{REFERENCES}

Albiladi, W. S., Abdeen, F. H. \& Lincoln, F. (2018). Learning English through movies: Adult English language learners' perceptions. Theory and Practice in Language Studies, 8(12), $1567-1574$. https://doi.org/10.17507/tpls.0812.01

Boggs, J. M., \& Petrie, D. W. (2008). The art of watching films (7th ed). McGraw-Hill.

Buckland, W. (2004). The cognitive semiotics of film. Cambridge University Press.

Byram, M. (1997). Teaching and assessing intercultural communicative competence. Multilingual Matters Ltd.

Chun, D., Kern, R. \& Smith, B. (2016). Technology in language use, language teaching, and language learning. The Modern Language Journal, 100, 64-80. https://doi.org/10.1111/modl.12302

Damen, L. (1987). Culture learning: The fifth dimension in the language classroom. Addison-Wesley Publishing Company.

Darmawangsa, D., Sukmayadi, V., \& Yahya A. H. (2020). First-year students' communication apprehension in learning French as foreign language. Indonesian Journal of Applied Linguistics, 10(2), 340-348. https://doi.org/10.17509/ijal.v10i2.28599

Fauziyah, R. A., \& Tjahjani, J. (2018). White supremacy symbolization and representation in "The Great Wall" and "Doctor Strange" movies. Advances in Social Science, Education and Humanities Research, 257, 24-30.

Fişek, E. (2018). Rethinking Intouchables: Race and performance in contemporary France. French Cultural Studies, 29(2), 190-205. https://doi.org/10.1177/0957155818755607

Gürses, H. (2020). Teaching with grief: An exploration of politics, pain, and power in Monsieur Lazhar. In V. Agnew, K. Konuk \& J. O. Newman (Eds.), Refugee routes: Telling, looking, protesting, redressing (pp. 139-155). De Gruyter. https://doi.org/10.14361/9783839450130-011

Habiňáková, E. (2016). Foreign language teaching with integration of cultural content. Mediterranean Journal of Social Sciences MCSER Publishing, 7(1), 299-305. https://doi.org/10.5901/mjss.2016.v7n1s1p299

Hammer, J. \& Swaffar, J. (2012). Assessing strategic cultural competency: Holistic approaches to student learning through media.
The Modern Language Journal, 96(2), 209233. https://doi.org/10.1111/j.15404781.2012.01335.x

Labidi, I. (2015). "Monsieur Lazhar": The ideal immigrant in the Neoliberal Québécois imagination. The Journal of North African Studies, 20(3), 374-390. https://doi.org/10.1080/13629387.2014.917584

Michael, C. (2014) Interpreting "Intouchables": Competing transnationalisms in contemporary French cinema. SubStance, 43(1), 123-137.

Nguyen, T. T. T. (2017). Integrating culture into language teaching and learning: Learner outcomes. The Reading Matrix: An International Online Journal, 17(1), 145-155.

Nurseto, T. (2011). Membuat media pembelajaran yang menarik. Jurnal Ekonomi dan Pendidikan, 8(1), 19-35.

Pfaff, F. (2014). Film and teaching of foreign languages and cultures. CLA Journal, 57(4), 279-284. https://www.jstor.org/stable/44324747

Rajprasit, K. (2020). Critical 'intercultural awareness' enhancement: Effects of using asynchronous online discussion with Thai tertiary students. Indonesian Journal of Applied Linguistics, 10(1), 118-131. https://doi.org/10.17509/ijal.v10i1.25020

Rice, A. (2013). Cinema for French conversation, Le cinéma en cours de français (4th ed). Focus Publishings.

Salim, S. K. (2017). Teaching language and culture. In Proceedings of the $8^{\text {th }}$ International Visible Conference on Educational Studies \& Applied Linguistics 2017 (pp. 464-470).

Schrambach, B. B. (2013, November). The UNDESIREABLES of 'Les Intouchables': A feminist critique of the French Blockbuster. Retrieved September 26, 2021, from http://digitalcommons.whitworth.edu/worldlan guagesfaculty/1

Stern, H. H. (1992). Issues and options in language teaching. Oxford University Press.

Tarte, K. B. (2014). Tu or vous? Forms of address and cultural understanding in "Monsieur Lazhar". The French Review, 87(3), 51-64. https://www.jstor.org/stable/24550380

Tognozzi, E. (2010). Teaching and evaluating language and culture through film. Italica, 87(1), 69-91. https://www.jstor.org/stable/20750678

Yalçın, N. (2013). Using movies in language classrooms means of understanding cultural diversity. Epiphany: Journal of Interdisciplinary Studies, 6(1), 259-271. https://doi.org/10.21533/epiphany.v6i1.65 